\title{
지속가능성과 경쟁력을 위한 스웨덴 국제개발협력의 전략 \\ : 스웨덴 복지모델의 관점1)
}

\section{I. 서 론}

2009년 기준으로 OECD DAC(Development Assistance Committee) 회원국들 중 해외개발원조 (ODA) 총량규모면에서 가장 큰 원조국은 미국, 프랑스, 독일, 영국, 일본 순으로 나타난다. 이 국가 들은 경제규모가 크기 때문에 원조 규모도 클 수밖에 없을 것이다. 그러나 이들 국가의 GNI 대비 $\mathrm{ODA}$ 비중은 $0.20 \%$ (미국), $0.46 \%$ (프랑스), $0.35 \%$ (독일), $0.52 \%$ (영국) $0.18 \%$ (일본)로 UN의 선진국 $\mathrm{ODA}$ 최소 목표치인 GNI 대비 $0.7 \%$ 를 달성하지는 못하고 있다. 반면, $0.7 \%$ 라는 목표치를 초과하는 나라는 덴마크(0.88\%), 룩셈부르크(1.01\%), 네덜란드(0.82\%), 노르웨이(1.06\%), 스웨덴(1.12\%) 5 개 국가이다. 2009년에 ODA 규모가 많이 증가한 나라는 노르웨이, 프랑스, 영국, 한국, 핀란드, 벨지 움, 스위스, 덴마크, 스웨덴, 미국 순으로 나타나고 있다. ${ }^{2)}$ 따라서 덴마크, 노르웨이, 스웨덴 등 노 르딕 국가들은 $\mathrm{ODA}$ 를 많이 하고 있으며, 이들 나라들은 2008년 경제위기 이후에도 그 규모가 증가

1) 이 글은 “스웨덴 국제개발협력과 스웨덴 모델”이라는 제목으로 『스칸디나비아 연구』12호(2011. 8)에 출간 예정인 논문을 약간 수정한 것임을 밝힌다.

2) http://www.oecd.org/document/0,3746,en_2649_34447_44981579_1_1_1_1,00.html 
하였음을 알 수 있다. 이 중 스웨덴은 GNI 대비 가장 많은 ODA를 하는 나라이다.

노르딕 국가들이 해외개발원조, 즉 국제개발협력을 많이 하는 배경과 이유에 대해서는 다양한 연 구가 진행되어 왔다. 특히, 복지국가와 사회민주주의라는 북유럽 공통적인 정체성이 노르딕 국가들 의 개발원조정책의 예외성을 설명하는데 자주 거론되어 왔다. 평등, 연대, 인간다운 삶, 삶의 질, 인 권과 휴머니즘, 자유 등 노르딕 국가들의 보편적 복지국가와 사회민주주의의 이념이 개발원조정책에 서도 구현되었다는 것이다. 따라서 이들 국가들의 관대한 해외개발원조는 국익을 위한 행위라기보다 규범에 의한 이상주의적 동기에서 비롯된다는 주장이 그것이다(Noel and Therien 1995). 이러한 국 내적 규범과 해외개발원조와의 상관성 주장은 노르딕 국가들의 해외개발원조의 예외성을 설명하는데 다양한 방식으로 동원되어 왔다. 그러나 이와 달리 국내적 규범과 해외개발원조와의 상관성을 고려 하지 않는 설명도 있다. 그 하나는 노르딕 국가들의 해외개발원조가 오히려 국제규범의 국내화에 의 한 것이었고 소국의 외교전략으로 봐야한다는 주장이 그것이다(김미경 2010). 즉, 노르딕 국가들의 관대한 해외원조를 그들의 국내적 규범과 정치의 국제화로 설명되기보다 그들의 특수한 상황에서 비 롯되었다는 것이다. 이 글은 노르딕 국가들의 ODA가 어떤 요인에 의해 비롯된 것인지, 언제부터, 왜 $\mathrm{ODA}$ 규모가 커졌고, 어떤 과정을 거쳐 원조가 확대되어 왔는지를 논의하고자 하는 것은 아니다. 물 론 이러한 논의는 매우 중요하며 많은 연구가 필요한 주제이다. 그러나 이 글은 다만 개별 국가의 해 외개발원조가 어떤 전략으로, 어떤 목표와 성과를 달성하는지에 대해 알아보고자 한다. 대표적인 노 르딕 국가이자 가장 많은 $\mathrm{ODA}$ 를 하고 있는 스웨덴의 국제개발협력의 전략과 특징을 원조 공여국, 즉 스웨덴의 발전 경험에서 찾아 보려는 것이다. 한 국가의 국제개발협력 전략은 원조 공여국의 고유한 역사적 발전 과정과 경험으로부터 영향을 받으며, 특히 노르딕 국가들은 이러한 특성이 두드러진다 는 것을 검토하는 것이다. 스웨덴의 국제개발협력이 관대할 뿐 아니라 지속가능성과 경쟁력을 갖는 것은 경쟁력이 뛰어나고 지속가능한 스웨덴 복지모델의 성격과 밀접한 관계가 있다고 보는 것이다. 이를 위해 스웨덴 $\mathrm{ODA}$ 의 내용과 성격을 간략히 검토 한 후 스웨덴 복지모델의 발전과정과 특징을 논 의하고자 한다. 이를 통해 스웨덴 $\mathrm{ODA}$ 의 성격과 스웨덴 복지모델의 역사적 발전 및 특징과의 연관성 을 찾아보고자 한다.

한 국가가 ODA 사업을 하고 그 활동을 확대하는 데에는 여러 이유가 있을 것이다. 또 그 이유가 갖는 장기적 의미와 단기적 목적이 다를 수도 있을 것이다. 스웨덴의 $\mathrm{ODA}$ 는 빈국이나 개발도상국의 빈곤추방을 기본 목표로 하고 있다. 이를 위해 경제성장, 경제·사회적 평등, 경제·정치적 독립성, 민주주의 발전, 환경보호, 성평등을 주요 목표로 하고 있다. 스웨덴 ODA의 구체적인 방법과 프로그 램들은 이러한 목표들을 최대한 달성할 수 있도록 설계되어 있고 이에 부합하도록 실행되고 있다. ${ }^{3)}$ 스웨덴의 해외개발원조는 사회적, 경제적 기회를 제공하고 사회안전망 확대를 위한 개발협력의 성격 을 갖고 있는데, 이는 스웨덴 복지모델의 성격과 밀접하게 연관되어 있다고 할 것이다. 스웨덴은 성

3) http://www.sida.se/English/ 
장과 복지를 성공적으로 양립시켜 온 나라로써 성장친화적 복지전략을 지속해 왔는데, 이는 스웨덴 의 개발협력 전략과 친화성을 가지고 있기 때문이다. 스웨덴의 성장과 복지전략은 경제성장, 경제 · 사회적 평등, 경제 - 정치적 독립성, 민주주의 발전, 성평등을 목표로 하였고, 세계적으로 괄목할만한 성과를 거두었다. 지속가능하고 경쟁력 있는 개발협력을 위해 스웨덴이 선택한 전략이 무엇이며, 이 러한 선택이 스웨덴의 역사적 발전과 어떤 연관이 있는지를 살펴볼 것이다.

\section{II. 스웨덴 국제개발협력의 현황과 성격}

\section{1. 적극적이고 관대한 국제개발협력}

스웨덴의 개발협력은 적극적이고 관대하다는 특징을 갖는다. 무엇보다 GNI 대비 개발원조 비중이 매우 크며 이를 오랜 기간 유지해 왔다는 점이다. 또한 사업의 성과에 대한 평가, 비용에 대한 철저 한 관리 등으로 개발협력 사업의 성과와 효율성을 높이고 있다. 스웨덴은 1965년에 DAC에 가입하였 으며, 2009년 GNI 대비 ODA 비율이 $1.12 \%$ 로 세계 최고 수준의 국제개발협력 활동을 하고 있다. 국 제개발협력에 대한 전문 인력 확충, 관련 기관간 조정 및 정책설정 등을 목적으로 외교부 산하에 국제 개발협력장관직(Minister for International Development Cooperation)을 만들었다. ${ }^{4)}$ 그러나 스웨덴의 국제개발협력 업무를 독자적으로 총괄하는 정부기관은 Sida(The Swedish Agency for International Development Cooperation)이다.

Sida는 1995년 기존의 4개의 스웨덴 해외원조기관을 통합함으로써 설립되었다. Bureau of Investment and Technology of Sweden(BITS), Sweden Agency for Research and Economic Cooperation(SAREC), Sida 전신인 SIDA, 그리고 SWEDE CORP 이 그것이다. 1990년대는 정책과 재정의 효율성을 높이기 위해 스웨덴의 공공부문에 대한 개혁이 본격적으로 추진된 시기였는데 Sida의 설립 또한 그러한 개혁의 일환 이었던 것이다. 또한 개발협력 제공기관 간 조정을 강화하고 개발협력정책의 일관성 제고를 위해 2008년 부터 Sida의 구조개혁을 실시하였다. Sida는 2011년 1월 1일에 더 효과적이고 더 효율적인 조직으로 새롭 게 개편되었다. Sida는 전통적인 외교업무와 구분되어 분권화된 시스템 속에서 독립성과 책임성을 가지 고 있다.

스웨덴의 개발원조를 보면 스웨덴만의 특별한 방식과 프로그램을 확인할 수 있다. 개발원조 방식 은 $\mathrm{NGO}$ 를 통해 이루어지는 방식이 있는데, 300 개 이상의 스웨덴 $\mathrm{NGO}$ 들이 이러한 활동을 하고 있 다. 그 다음으로 중요한 것이 UN, 세계은행 등 국제기구를 통한 다자간협력 방식이다. 또한 개도국 파트너에 직접 지원하는 지원금과 원조가 있다. 스웨덴의 기술과 개도국을 연결하는 개발협력 방식

4) http://www.swedishbulletin.se/sb/articles/0604-jamtin.shtml 
이 중요한데 Sida는 금융지원과 감독을 책임지고 있다. 최근 들어서는 스웨덴 기업, 대학, 정부기관 등이 스웨덴 내에서 개도국에서 온 연수생들을 교육 훈련시키는 국제훈련프로그램을 적극적으로 실 시하고 있다. 이러한 International Training Programmes은 스웨덴의 지식, 경험, 기술 등을 교육 하는 것으로 프로그램 종료 3년 후에 평가를 실시한다고 한다. 또한 스웨덴 연구자가 Sida 연구비로 국제기관 또는 개도국과 연구협력 활동을 하는 프로그램, 개발협력 컨설턴트 신탁기금 프로그램 등 이 있다.

중요한 것은 이러한 활동방식이 일방적 단순원조가 아니라 상호간에 협력을 통해 국제개발협력의 의의와 성과를 제고하는데 있다. Sida는 스웨덴의 기업, 대중운동단체, 대학, 정부기구, 시민사회단 체 등과 파트너십을 구축하여 지식, 기술, 자금 등 다양한 자원을 아프리카, 아시아, 남미, 중동유럽 국가들에 제공한다. 주요 사업 분야는 경제, 사회인프라, 환경 및 물자원 관리, 도시발전이다. 구체 적으로는 가난한 사람들을 어떻게 빈곤에서 탈출시키는가 하는 문제이다. Innovations Against Poverty Programme은 혁신을 통해 빈곤을 추방하려는 Sida의 새로운 프로그램으로 사회적 기업가 로서 기업이 Sida의 펀드로 자신의 역량을 이러한 활동에 투입하는 것이다. 그동안 스웨덴 상공회의 소는 빈국이나 개도국에서 활동하는 스웨덴 기업들에 해외무역기회를 만들어주고 정보제공, 컨설팅 등의 서비스를 제공해 왔다. 이들 기업들이 개발협력에서도 기술과 다양한 서비스를 제공하게 만드 는 것이다.

농촌 및 낙후된 지역의 양성평등을 위한 지원도 $\mathrm{Sida}$ 의 대표적인 사업이다. 아프리카 국가들은 물 론 개발도상국 여성의 인권을 강조하고 여성의 지위향상을 위해 농가 소득증대와 젠더 교육 등에 적 극적이다. 이를 통해 남녀 모두의 인력자원을 계발하여 지속가능한 경제발전을 위한 인적자원을 향 상시키는데 기여하고 있다. 베트남에 대한 개발원조에서도 농촌지역 및 낙후된 지역의 양성 평등을 위해 젠더기금을 조성하여 베트남 여성의 인권을 증진시키고자 한다. ${ }^{5)}$

스웨덴의 적극적이고 관대한 국제개발협력 활동은 스웨덴 복지모델과 상관성이 크다. 스웨덴 복지 정책은 적극적이고 생산적인 성격으로 잘 알려져 있다. 단순히 시혜나 도움을 주는 것이 아니라 모든 사회구성원들이 각각의 능력을 가지고 사회에 참여하여 책임과 권리를 갖는 것이다. 실업자, 저학력 또는 저소득층에 대해 교육 및 훈련으로 개인의 역량을 강화하고 사회적, 경제적 기회를 부여하는 것 이 대표적이다. 특히, 성평등과 여성의 역량강화(Empowerment)에 대한 강조는 스웨덴 모델의 최고 의 강점이자 특징이다.

$\mathrm{OECD}$ 는 개발협력에서 스웨덴의 역할을 중요하게 평가하고 있다. 1965 년부터 지금까지 스웨덴의 개발협력 목표는 가난한 사람들의 생활수준을 향상시키는데 있다. ${ }^{6)}$ 이러한 목표는 스웨덴이 경제 및 사회발전을 달성한 역사적 과정과 밀접하게 연관되어 있다. 빈곤타파를 위해 총체적이고 다차원적으 로 경제성장, 경제사회적 평등, 경제정치적 독립, 민주주의 발전, 환경보호, 성평등을 중시하고 이러

5) 'Our work in Vietnam', Sida Oct. 13, 2010

6) OECD 'Sweden's leading role in development co-operation' Sweden (2000), Development Co-operation Review 
한 목적들을 달성함으로써 가능하다고 본다. 이러한 6 개의 목적은 각각 별개로 추구되는 것이 아니 라 상호 연관됨으로써 빈곤타파라는 궁극적인 목표를 달성할 수 있다는 것이다. 스웨덴의 해외개발 원조는 이러한 목표에 잘 부합하고 있다. 원조는 주로 사하라 이남의 빈곤국에 집중되어 있으며, 교 육 및 사회서비스 비중이 높다고 한다. 그리고 제도개혁에 적극적이다. 이러한 스웨덴의 개발협력 활 동의 특징은 스웨덴 복지모델과 매우 유사하다. 스웨덴은 OECD 등 국제기구에서 개발협력과 빈곤추 방을 위한 정책입안에 주도적 역할을 하고 있으며, 자국의 지원 프로그램의 효과성을 높이기 위한 새 로운 방안 도입에도 적극적이다.

스웨덴은 다른 원조공여국과 다르게 해외개발원조의 효과성에 큰 관심을 가지고 이를 제고시키기 위해 노력하고 있다. 자국의 개발원조가 원조를 받는 나라의 빈곤수준을 감소시키는데 실제로 기여 하고 있는지, 사회적 인프라의 향상에 도움에 되는지, 경제성장을 촉진시키는지 등을 모니터링하는 것이다. 원조의 효과성에 영향을 미치는 중요한 변인으로서 원조공여국과 수원국간의 관계, 협력국 의 정치사회적 조건, 원조공여국간 상호조정 등이 있다고 한다(김미경 2010). 그럼에도 원조의 효과 성에 대한 관심 자체가 한 국가의 원조정책에 결정적인 영향을 주지는 않고 더구나 대부분의 국가와 그들의 시민사회는 자국이 제공하는 원조의 산출적 효과에 대해 무지하다(Mosley 1985; 김미경 2010)고 한다. 그러나 스웨덴은 적극적으로 개발원조의 효과성을 높이기 위한 프로그램을 실시하고 있다는 점에서 스웨덴의 차별성이 두드러진다. 이는 효율성과 효과성을 중시하는 스웨덴 복지모델의 특성이기도 하다.

\section{2. 스웨덴 국제개발협력과 스웨덴 복지모델}

$\mathrm{ODA}$ 정책에 있어서 고유한 노르딕 모델의 성격이 있는가. 김미경(2010)의 연구에 의하면 노르딕 국가들의 $\mathrm{ODA}$ 정책은 $\mathrm{OECD}$ 의 다른 국가들과 비교하여 특징이 있다고 한다. 첫째, 원조의 규모이 다. GNI 대비 총 ODA 규모가 DAC 국가들의 평균수준을 훨씬 상회하고 있다는 점이다. 둘째, 제공된 원조의 특성이다. 무상원조의 비중이 높다는 점이다. 무상원조의 비중은 총 ODA 규모와 함께 각 국가 가 수행하는 원조정책의 관대성(Generosity)을 평가할 때 중요하게 사용되는 지표이다.

셋째, 노르딕 국가들은 원조대상과 원조의 목적에서도 차이가 있다. 주로 최빈국에 원조를 제고하 며, 인권개선을 원조 제공의 중요한 목적과 조건으로 설정하고 있다(Gate Hoeffler 2004) 원조와 인 권개선을 연계시키는 것은 1960 년대 초반부터 스웨덴을 주축으로 하는 노르딕 국가들의 일관된 정책 방향이었다(Selbervik 2006). 특히 굿 거버넌스(Good Governance)와 인권개선이 원조 협력국의 주 인의식을 강화시키는데 중요한 역할을 한다. 이는 원조의 효과성 제고에 직접적인 영향을 미치는 협 력국의 중요한 사회적 조건이기 때문이다. 이는 노르딕 국가들의 원조정책에 내재된 인도주의적 특 성과 규범적 성격을 반영하는 것이라고 한다. 마지막으로 노르딕 국가들은 원조의 지역적 집중이라 는 특징이 있다. 그들은 최빈국에 대한 원조를 중시하였기 때문에 최빈국들이 사하라 이남 아프리카 
에 편중되어 있다는 점에서 노르딕 국가들의 아프리카 집중은 노르딕 국가들의 인도주의적 원조정책 을 반영한다고 볼 수 있다. 이들 아프리카 국가들과는 통상적 이해관계가 없어 비전략적 동기(NonStrategic Motivation)라는 특징을 보여준다. 또한 특정한 원조협력국과 장기적이고 안정적인 관계 를 지속함으로써 상호신뢰를 구축해 오고 있다는 점이다.

스웨덴은 효율적인 국제개발협력을 수행하고 있으며, Sida는 스웨덴 정부의 국제개발협력 관련 업 무를 담당하는 기구이다. Sida는 세계의 빈곤추방을 기본 임무로 하고 있으며, 가난한 사람들이 그들 의 삶의 조건을 스스로 향상시킬 수 있도록 지원하고 기여하는 것을 목적으로 하고 있다. 빈국의 교 육과 일자리 만들기 사업, 민주주의를 위한 협력사업, 공공기관 투명성 제고 사업, 공공부문 재정관 리 개혁 지원사업, 역량강화 및 제도구축 사업, 성폭력추방사업 등을 통해 빈국의 제반 여건을 향상 시키는데 노력하고 있다. 이러한 사업을 위해 시민사회단체(CSOs)를 지원하고 연결하는 역할을 하 고 있다. 스웨덴은 역사적으로 복지국가의 발전과 투명하고 개방적인 국가를 만드는데 시민사회의 역할이 중요했다(Trägårdh 2007). 자율적이고 민주적인 시민사회단체들이 다양한 풀뿌리 시민운동 을 통해 사회구성원간 협동의식과 신뢰를 고양하여 사회자본을 축적하는데 기여해 왔다. 활기있고 역량있는 스웨덴 시민사회는 개인의 자유와 참여를 위한 중요한 조건이 될 뿐 아니라 국가는 물론 공 정한 기업과 시장의 성격에도 영향을 미쳐왔다.

Sida는 대외원조의 효율적인 배분을 위해 엄격한 기준으로 자국의 $\mathrm{NGO}$ 를 선정, 지원하고 있다. 구체적으로 구제가 가능한지, 효율적인지, 실행가능한지, 유지할 수 있는지, 협상이 가능한지, 위험 관리가 가능한지를 평가한 후 원조의 분배를 하게 된다. 또한 사업적인 지원 외에도 빈곤을 줄이기 위한 활동, 가난한 사람들의 권리, 양성평등, 환경, 질병 등의 사업에도 참여하고 있다. 무상원조비 율이 거의 $100 \%$ 이며 프로젝트 원조가 스웨덴의 양자 간 원조의 거의 절반 이상을 차지하고 있다. 주 로 사회 인프라 및 서비스 분야가 차지하는 비중이 가장 크고, 그 중 공공행정 및 시민사회 분야와 보건 분야가 가장 높은 비율을 차지하고 있다. 스웨덴의 해외개발원조는 인도적 지원이 차지하는 비 중과 NGO에 지원하는 비중이 높은 것으로 나타난다. 그만큼 시민사회의 역량강화를 통해 원조의 효 과를 높이려는 스웨덴의 해외원조 전략을 보여준다.

정책적으로는 개발협력 사업 및 지원 규모의 내실화 및 원조 효과성 제고 및 원조의 질 향상을 제 고하고 있다. 성과중심의 관리를 강조하는 정책을 구사하고 있다. 외교부와 Sida 간의 업무분업을 통 해 효율성을 제고시키는 반면, 현장에서는 두 기관의 유기적 결합을 통한 효율성 제고에 노력하고 있 다. 또한 환경과 기후변화, 역량개발, 인도주의, 협력국 내 민주주의 발전, 성평등 등의 이슈에 대한 개발협력의 효율적인 관리 및 국내외 시민사회와의 협력 증진을 도모하고 있다. 개발협력의 우선 지 원 분야는 민주주의와 인권, 환경과 기후변화, 성평등 및 개발에서의 여성 역할 등이다.

스웨덴 사례는 원조공여국의 해외원조정책이 어떤 요인에 의해 결정되는가라는 측면에서 주로 국 내적 결정요인에 관한 연구의 분석대상이 되어 왔다고 한다. 즉, 스웨덴은 왜 해외원조를 하고, 특히 다른 국가들보다 더 많은 해외원조를 하는가라는 질문에 대해 국내적 요소가 중요하다고 보는 것이 
다. 그동안 국민소득수준, 국내경제상황, 정부재정 및 지출수준, 실업 등 국내경제관련 변수들과 $\mathrm{ODA}$ 에 대한 공공여론과 국내적 지지, 집권당의 정치적 이념, 국내 사회복지정책의 유형 등 정치경제 적 변수들이 많이 논의되었다(김미경 2010: Milner and Tingley 2010). 즉, 스웨덴은 국민소득과 재 정지출이 높음에도 재정이 안정되어 있고 사회민주당의 평등 및 연대 이념이 보편적 복지국가와 어 우러져 해외원조를 많이 하게 만든다는 것이다. 또한 국내적 규범과 해외원조간의 상관성에 관한 연 구는 국가행위를 설명함에 있어 이상주의적 혹은 도덕주의적 동기의 중요성을 강조하는 자유주의적 시각을 반영한다고 한다. 자유주의 시각은 해외원조를 국내사회에 깊이 내재화된 제도와 규범의 국 제화로 인식하는 경향이 강하다. 노르딕 국가들의 원조정책의 예외성을 사민주의적 복지국가라는 그 들 국가들의 공통적인 정체성의 관점에서 설명하는 연구가 그것이다(Lumsdaine 1993: Noel and Therien 1995).

이 글은 왜 해외개발원조를 하는지, 특히 왜 그렇게 막대한 규모의 해외원조를 하는지에 대한 논 의가 아니라 어떻게 개발원조를 하는가에 대해 논의하는 것이다. 즉, 개발원조를 왜 하는지에 대해서 는 국내적 요인과 외부적 요인이 있겠지만, 개발원조를 어떻게 하고 어떤 목적과 성과를 내는지는 국 내적 요인이 중요하다는 점을 보여주고자 한다. 이 글이 강조하고자 하는 것은 스웨덴의 구체적인 개 발협력 전략과 프로그램이 스웨덴의 복지국가 전략 및 정책의 성격과 중요한 관계가 있다는 점이다. 이제 스웨덴 개발협력의 현황과 성격이 스웨덴 복지모델과 어떤 유사성이 있는지를 파악하기 위해 스웨덴 복지모델의 주요 특성을 검토하고자 한다.

\section{III. 스웨덴 복지모델의 발전과 성격7)}

\section{1. 평등과 연대의 보편적 복지모델}

스웨덴은 평등과 연대의 복지국가를 실현해온 국격(國格)이 높은 나라로 잘 알려져 있다. 삶의 질 이 높을 뿐 아니라 경제상황도 매우 양호하여 국민소득이 높고 국가경쟁력 순위 또한 세계 최상위권 을 유지하고 있다. 스웨덴 복지국가는 단기적 소득상실, 빈곤에 처한 개인들의 경제적 안전을 보장해 주면서 평등하고 인간다운 삶을 보장해주고 있다. 장기적으로는 교육, 의료, 보육 등 공공사회서비스 를 통해 사회구성원의 사회적, 경제적 기회를 보장해주고 있다. 개인의 시장적 가치와 별 상관없이 인간다운 생활을 누릴 수 있는 복지와 경제적으로 부강한 나라를 실현해온 스웨덴은 많은 나라들에 게 선망의 대상이 되어 왔다.

이러한 스웨덴 복지국가는 다른 선진국들과 비교하여 평등과 연대의 사회민주주의적 복지국가로

7) 이 부분은 주로 김인춘(2007) 내용에서 요약하였다. 
특징지어져 왔다(Esping-Andersen 1990). 스웨덴, 노르웨이, 덴마크 등 사회민주주의적 복지국가 유형은 일반적으로 노르딕 모델이라 불리는데 이러한 '스칸디나비안 예외주의'는 유럽 내에서도 잘 알려져 있다. 평등과 연대라는 사회주의적 이상을 자본주의적 시장원리와 의회민주주의를 통해 달성 한 것이다. 스웨덴의 사회민주주의적 복지국가가 역사적으로 어떻게 성립되고 발전되어 왔는지 간단 히 살펴보겠다.

스웨덴 모델하면 복지국가가 연상될 만큼 보편적이고 관대하며 포괄적인 복지정책이 제도적으로 확립되어 있다. 대부분 조세수입을 재원으로 하여 저소득층을 포함, 모든 국민을 대상으로 완벽한 소 득보장과 다양한 공공 사회서비스를 제공해오고 있다. 스웨덴 복지국가의 기초는 1891년 자발적인 건강보험에 대해 국가가 기여금을 지원하면서부터 시작되어 1901년에 고용주 책임을 강제한 산재보 험법이, 1913년에는 연금제도가, 1931년에는 병가보험이 각각 도입되었다. 1932년에 집권한 사회민 주당은 정치적 프로젝트의 하나로 복지개혁을 지속적으로 추진해 왔는데 모든 사회구성원의 주거권 을 확립하기 위한 주거개혁도 그 중 하나였다. 2차 대전 후 1938 년 작성된 사회복지위원회의 보고서 를 기반으로 복지개혁을 추진하여 1950년대 초에 기본적인 복지국가를 완성시켰다. 1946년 연금개 혁을 시작으로 1949년에는 산업재해보상법이, 1954년에는 아동수당법과 주택수당법이, 그리고 1955 년에는 병가보험법이 통과됨으로써 보편적인 사회보험제도가 도입되었던 것이다. 1955 년에는 국민 모두에게 거의 무료에 가까운 의료서비스제도가 시작되었다.

스웨덴은 유럽 내에서 후발 자본주의 국가에 속한다. 19 세기 말부터 산업화가 급속히 진행되어 스 웨덴 사회는 기본적으로 자본가와 노동계급으로 분화, 발전되었고, 정치적 동원 또한 이러한 계급에 기반하여 이루어졌다. 1898년에 생산직노조총연맹(LO)이 창설되었고 노동운동의 급속한 성장으로 1907 년 산업노동자의 $48 \%$ 가 노동조합에 가입하게 되었다. 이에 따라 노동세력은 자본계급과 힘의 균형을 이룸으로써 정치적으로 중요한 주체로 성장하게 되었다. 스웨덴의 복지국가 발전과 민주주의 의 완성에는 사회민주주의자들 뿐 아니라 자유주의자들이 중요한 역할을 하였다. 사회민주당(이하 사민당)은 노동운동의 지지를 받은 반면, 자유당은 도시 부르주아지와 농민층의 지지를 받고 있었다. 자유당은 이념적으로 사회적 자유주의를 표방했는데 사민당과 함께 보통선거권을 위해 투쟁하여 1919년 보편적인 평등참정권이 도입되는데 큰 역할을 하였다. 1921년에는 여성에게도 평등선거권이 부여되었다.

스웨덴의 복지정책은 실제로 사회민주당이 집권하기 이전부터 도입되기 시작하였다. 1907년 노령 연금위원회가 구성되고 1913년 연금법이 발효되면서 세계 최초로 보편적인 국민연금제도가 도입되었 다. 1889 년에 창당된 스웨덴 사회민주당은 사회혁명 대신 합법적 방식으로 정치적 정의, 사회적 정 의, 경제적 정의를 위한 사회개혁을 목표로 했다. 실용주의를 선택한 사회민주당은 당시 국민들의 요 구사항이었던 고용과 복지를 충족시키기 위한 사회정책에 주력했다. 사민당은 1920년 최초로 소수정 부를 구성했고 1932년 다수당이 되어 집권하였다. 1928년 한손(Hansson) 사민당 당수는 의회 연설 에서 국가는 모든 국민의 생존을 보장하는 '국민의 집(Folkhem: the Home of the People), 즉 복지 
국가가 되어야 한다고 주장했다. '국민의 집’이라는 슬로건은 국가가 모든 국민의 안락한 집과 같은 존재가 되어야 한다는 공동체적 이념을 나타낸 것으로, 보편적 복지국가의 이념이 사민당의 주요 목 표임을 분명히 하였다.

이에 따라 스웨덴 복지국가는 1930년대 한손 수상(1932-46년 재임)의 사민당 정부가 빈곤 추방과 인간적인 삶을 보장하려는 계획으로 본격화되었다. 이 계획은 국가의 세금으로 모든 국민에게 어떤 경우에도 기본적인 경제적 안전을 보장하며, 보편적인 복지국가를 지향했다. 1930 년대 초 경제공황 시기에 일반 국민의 전반적인 생활 여건 향상을 위해 적극적 노동시장정책, 주택건설보조금제도, 특 별실업보험제도 등 스웨덴식 뉴딜정책이 시행되었다. 1938년 사회복지위원회가 구성되었고 평등주 의적 보편주의 원칙하에 연금, 가족수당, 의료보험, 산재보험 등이 도입되었다.

2 차 세계대전 이후 사회개혁 작업이 다시 계속되어 공정한 분배를 위한 정책, 결손가정 지원정책, 교육제도의 개혁 등이 중점적으로 시행되었다. 사회보험제도는 완벽하게 도입되었는데, 1913년의 연 금법을 확대하여 1946년 새로운 연금법이 도입된 것이 그 하나이다. 임산부, 어린이, 학생, 환자, 장 애인, 실업자, 노인 등 사회적 취약계층에 대해 국가는 이들에게 필요한 공공사회서비스를 무상 또는 저렴한 비용으로 제공하였다. 스웨덴의 공공사회서비스는 보육, 교육, 보건 등으로 확대되어 모든 사 회구성원들이 그 혜택을 받고 있다. 스웨덴 모델의 최고의 성과인 복지국가는 유권자들의 정치적 선 택에 큰 영향을 미쳐왔다. 복지국가가 최소한의 인간적 삶의 보장 뿐 아니라, 인적자본, 고용능력, 소득 등을 향상시켜 중산층으로의 상향 평준화에 중요한 역할을 해왔기 때문이다. '일하는 복지 (Workfare)', '학습복지(Learnfare)'의 개념이 복지제도에 강하게 내재되어 있어 소득재분배의 효과 뿐 아니라 경제의 효율성 측면에서도 긍정적으로 작용해 왔던 것이다.

\section{2. 사회적 합의에 의한 스웨덴 복지모델 구축}

스웨덴 복지모델은 사회민주당 혼자 발전시켜온 것이 아니라 좌우 정당간, 노동과 기업 등 주요 사회세력간 합의로 발전되어 왔다. 그만큼 효율성과 효과성을 높일 수 있는 기반이 존재했다. 사회민 주당은 1932 년 집권 이후 높은 경제성장과 완전고용의 경제적 토대 위에 임금평등과 보편적인 복지 국가라는 스웨덴 모델을 발전시켜 왔다. 주요 정치사회세력에 대해 민주적인 정책결정 과정에의 참 여를 제도화한 사회 코포라티즘(Social Corporatism)에 의한 사회적 조정과 합의제도가 스웨덴 모델 의 핵심 정책에 중요한 바탕이 되었다. 이러한 정책과 제도는 1938년 살츠쉐바덴(Saltsj baden) 기 본협약이라는 사회적 대타협을 계기로 발전하기 시작하여 1960년대에 완전히 제도화되면서 명실상 부한 스웨덴 모델로 나타나게 되었다. 이 과정에서 여러 갈등과 어려움이 있었지만 정치지도자, 기업 가, 노조지도자들, 그리고 관료들이 높은 경제성장을 달성하고 최고의 복지국가로 풍요롭고 평등한 사회를 만들겠다는 국가적 목표를 위해 부단히 노력하고 협력해왔기 때문에 가능했던 것이다.

스웨덴 사회민주주의자들은 '유연한 진보주의자들'이었으며, 실용적 개혁주의로 계급타협을 통한 
사회진보를 추구하였다. 1930 년대 초 경제공황으로 어려움에 처한 노동자들과 농민을 위해 사회민주 당은 1933년 농산물보조금과 공공일자리 사업을 서로 받아들이는 내용으로 농민당과 정책연합을 이 루기도 하였다. 1938년의 살츠쉐바덴 기본협약은 1933 년 사회민주당과 농민당의 정책연합에 필적하 는 성과였다. 두 정당간 정책연합, 즉 '적녹연맹’이 정치상황을 안정시켰듯이, 노사간 기본협약은 노 동시장 상황을 안정시켰기 때문이다. 이 두 성과는 향후 스웨덴 모델의 형성과 발전에 핵심적인 조건 이 되었다. 유럽대륙과 소련에서 권위주의적 정권이 창궐하고 획일적인 전체주의 사상이 휩쓸던 1930년대에 스웨덴은 계급연합과 계급타협을 통해 정치문제와 노동문제를 해결하였던 것이다. 당시 의 권위주의적, 전체주의적 국가들과 달리, 스웨덴은 인간의 존엄과 자유를 존중하고 자율적인 시민 사회를 발전시켜왔다. '열린사회'를 지향했던 것이다.

사민주의자들은 당시 유럽 및 소련의 많은 사회주의자들과 달리 이상주의에 경도된 사회주의 엘리 트도, 교조적 사회주의자들도 아니었다. 중요한 것은 스웨덴의 민주적 사회주의자들이 인간의 존엄 에 대한 신념과 물질적 조건에 대한 신념을 동시에 지녔다는 점이다. 자신의 길을 이념으로 포장하기 보다 현실에 기반한 실용으로 채워왔다. 평등과 연대의 인간주의적 또는 사회주의적 이상은 자본주 의적 성공으로 이루진다고 보았다. 이에 따라 스웨덴 특유의 높은 수준의 보편적 복지국가와 효율과 성장을 중시하는 경제제도가 동시에 발전하게 되었다. 사회민주당은 주요 정당과 함께 계급연합과 계급타협을 바탕으로 1940 년대 이후 경제성장, 완전고용, 복지국가를 동시에 지향하는 사회민주주의 복지국가의 제도적 기반을 확실히 구축하게 되었고, 후발 산업국이었던 스웨덴은 유럽 최고의 부자 국가로 1960년대에 서구 복지국가의 모델로 부상하였던 것이다.

계급타협이 스웨덴과 같은 작은 나라들에서 더 적극적이었던 데에는 정치사회적, 경제적 이유가 있었다. 노동운동을 중심으로 한 개혁적 좌파가 점진적으로 정치적 힘을 확대시켜 온 것이 중요하였 다. 보통선거권과 비례대표제의 도입으로 상이한 정치주체 간 권력공유가 가능해진 것도 중요한 이 유가 되었다. 또한 경제적으로 대외의존도가 높은 개방경제 국가에서 입장이 상충하는 이익집단간 사회적 조정과 합의의 필요성이 커졌고, 이에 따라 노사협력에 기반한 코포라티즘은 1960 년대까지 경제성장과 사회평화에 기여하면서 안정적으로 작동되었던 것이다. 경제· 사회정책에서 국가 차원의 사회적 파트너십을 구축하여 이익집단, 국가관료, 정당 간 지속적인 협상을 통해 갈등문제를 공식/ 비공식적으로 조정해 왔기 때문이다.

\section{3. 실용적 개혁주의와 생산적 복지국가}

스웨덴 노동운동이 계급타협의 방식으로 의회민주주의와 복지국가를 지향할 수 있었던 것은 사회 민주당의 실용적 개혁주의 덕분이었다. 사회민주당의 실용적 개혁주의 정책노선은 일찍부터 스탈린 식 계획경제와 미국식 시장경제의 성공적 타협인 '가운데 길(the Middle Way)'이라는 평가를 받았는 데, 1930년대 들어 스웨덴 사회민주당이 구축한 사회민주주의 체제는 사회주의에 관한 새로운 관점 
을 보여주었다. 생산수단, 즉, 소유의 사회화는 거부되었지만 자본의 사회적 성격 및 생산의 민주적 통제를 강조하였던 것이다. 그것은 소득 및 소비의 사회화, 그리고 사유재산에 대한 통제의 사회화를 뜻하게 되었는데, 이는 국가에 의한 광범위한 사회개혁, 경제활동과 노동시장에 대한 적극적인 개입 을 통해 이루어져야 할 목표가 되었다.

2차 대전이 끝나자 스웨덴은 완전고용사회에서 삶의 질과 복지를 어떻게 보장할 것인가 하는 문제 에 지대한 관심을 갖게 되었다. 당시 사민당 정부는 사회적 합의에 따라 경제적 호황을 배경으로 복 지정치에 전념하게 되었다. 2차 대전 이후 점진적으로 구축된 경제 및 사회정책의 특징은 스웨덴 모 델의 핵심적 요소가 되었다. 사회민주주의자들은 경제 및 사회정책의 최고 목표로 경제적 안전 (Economic Security)과 평등주의를 주창하면서 완전고용과 임금평등, 경제성장과 복지국가를 지속 적으로 추구하였다. 전후에 도입된 중요한 제도들이 이러한 목표를 달성하기 위한 것이었고 스웨덴 모델을 발전시키는데 중요한 역할을 하였다. 전후 확고히 자리잡은 스웨덴 모델은 '원칙있는 실용주 의(Principled Pragmatism)'를 기반으로 평등과 연대를 이념으로 경제성장과 완전고용, 보편적 복지 국가를 추구하였다. 경제에 대한 규제는 완전고용을 목표로 노동시장에 적극적으로 개입하는 것을 특징으로 하였다. 전후 유럽대륙의 진보적인 분위기를 반영하듯, 우파 정당들도 사회민주당 정부의 경제개입 및 복지정책을 대폭 수용하였다.

사회민주당 정부는 1959년 사무직 중간계층에 유리한 '소득에 연계된 보충연금(Supplementary Pensions)'으로 공적연금을 개혁하였다. 1956년부터 연대임금정책을 실시하면서 근로자간의 임금격 차를 줄이기 시작하였다. 사무직에 유리한 연금개혁이었지만 노조는 저임 생산직 근로자의 임금수준 이 향상될 것을 기대할 수 있었다. 보충연금제도의 도입으로 대부분의 화이트칼라들은 노동계급과 더불어 복지국가의 강력한 지지자가 됨으로써 복지국가의 발전을 뒷받침했다. 연금개혁으로 사회민 주당은 전후 평등주의에 입각한 사회민주주의적 개혁을 사회 자유주의 방향으로 수정하였다. 모든 국민을 하나의 공동 연금체계에 포함시킨다는 목표를 위해 기존의 정률급여 원칙을 깨고 소득연계 급여라는 '규제된 불평등'을 수용한 것이다. 이로써 스웨덴의 사회정책은 새로운 방향을 갖게 되었 다. 이 시기 사회민주당의 에를란더(Erlander) 총리(재임 1946-68)는 개인의 자유와 공공의 책임이 조화되는 보편적 복지국가를 완성하였다.

보충연금은 전적으로 세금에 의해 운용되는 보편적 정률 국민연금과 달리 세금 외에 사용자와 근 로자가 공동으로 기여금을 부담하였다. 전후 스웨덴 복지국가의 핵심이 시민권에 기반한 1946 년 국 민연금체제에서 기여원칙의 퇴직연금인 1959년 보충연금체제로 이동하였다. 이에 따라 사회민주당 은 민간 및 공공부문, 생산직 및 사무직 모두를 포괄하는 '하나의 중산층'을 만들게 되었다. 그 결과, 1960년대와 1970년대에 복지지출이 급격히 팽창하면서 스웨덴 복지국가는 전성기를 맞게 되었다. 1960년까지 세금이나 공공지출 수준이 다른 선진국가들과 별 차이가 없었지만 그 후 복지지출의 팽 창은 조세부담과 공공지출을 세계 최고로 만들었다. 소득세는 1970 년대 이후 약 20년 동안 최고 세 율이 $80 \%$ 에 달했다. 이러한 세금은 다시 정부지출에 의해 사회보험과 공공부조 등의 소득재분배정 
책, 교육, 의료, 탁아 등의 공공 사회서비스정책에 투자되었다.

1930 70년까지 스웨덴은 자본소득에 대한 낮은 과세로 기업가정신을 북돋았고 산업합리화와 구 조조정의 압력은 근로윤리를 제고시키는 역할을 하였다. 임금과 복지는 높은 수준에서 평준화되었지 만 무임승차에 대한 사회적 규율은 엄격했다. 사회민주당의 핵심 이념의 하나인 완전고용정책은 일 할 수 있는 사람은 모두 일하게 만들었다. 스웨덴의 복지국가는 처음부터 '일하는 복지(Workfare)'였 던 것이다. 대신, 높은 임금을 보장했고 일을 보다 인간적이고 여유로운 환경에서 할 수 있게 했다는 데 특징이 있다 할 것이다. 그러나 연대임금정책에 따른 산업합리화로 실업의 위험이 있기 때문에 일 을 열심히 해야 할 (디스)인센티브가 존재했다. 연대임금정책이란 노사정 합의에 의해 1950 년대 중 반부터 시행된 중요한 정책으로, 기업의 지불능력과 관계없이 동일한 노동에 대해서 균등한 임금을 지급하는 것이다. 업계 평균의 임금을 정하고 이를 획일적으로 적용하는 연대임금은 생산성이 높은 기업의 근로자들은 임금인상을 그만큼 자제하는 반면, 실적이 좋지 않은 기업의 근로자는 기업의 지 불능력을 초과하는 임금을 받게 된다. 이는 기업이윤과 임금간 상관관계를 차단시키고 저임금부문의 임금상승을 우선했기 때문에 산업간, 기업간 임금격차를 축소시켰다.

정부의 적극적 노동시장정책은 노동이동을 제약하는 요소들을 완화시킴으로써 한계부문에서 발생 한 실업자들을 생산성이 높은 부문으로 이동시켰다. 시장원리에 따라 생산성이 높은 부문으로 자원 이 이동함으로서 전체적으로 경제의 효율성이 상향평준화되었다. 스웨덴 노동시장이 유연성을 갖게 된 것은 단순히 해고 등을 통한 수량적 유연성보다 임금유연성과 노동력의 질적 유연성, 노동력 이동 을 제고했기 때문이다. '직장'이 아니라 '고용'을 보장하는 스웨덴 특유의 적극적 노동시장정책으로 노동시장의 유연성을 확보하였던 것이다. 연대임금정책과 적극적 노동시장정책은 상호보완적 관계 속에서 완전고용, 거시경제적 안정, 평등이라는 목표를 실현하는데 중요한 역할을 하였다.

\section{4. 세계화와 복지개혁: 복지국가의 경쟁력 강화}

2 차 대전 후 경제적 호황, 유권자들의 정치적 압력, 정당간 경쟁, 진보적 정치 환경 등으로 스웨덴 복지국가는 원래의 구상 이상으로 계속 팽창해 왔다. 복지국가가 최고조에 달한 1970 년대에 세계적 경제위기가 발생하였고 이에 따라 적지 않은 부작용이 나타나게 되었다. 무엇보다 재정적자 문제가 심 각하였다. 경제상황이 악화되면서 세금수입은 줄고 복지지출이 크게 늘었기 때문이다. 병가급여, 산재 급여, 편부모지원, 선택적 주거보조금, 공공부조 및 조기퇴직보조금 등에서는 도덕적 해이 현상도 나 타났다. 급진적 분배정책에도 불구하고 공공부조급여를 받는 빈곤가구도 늘어났다. 높은 질을 자랑해 온 공공 사회서비스는 효율성 문제, 제한된 소비자선택, 경쟁의 결여 등의 문제를 가지고 있다.

이러한 상황에서 스웨덴 복지국가는 보수세력으로부터 국제경쟁력을 떨어뜨리는 주요 요인으로 비판을 받아 왔다. 이들은 높은 수준의 국가복지와 고율의 세금이 노동과 교육에 대한 동기를 약화시 켜 양질의 노동력 공급을 저하시킨다고 주장하여 왔다. 또한 완전고용을 위한 고용보호 규제들이 노 
동시장의 경직성을 초래해 노동력의 효율적 배분을 방해하고, 연대임금과 높은 사회보장 비용으로 인한 노동비용의 상승이 스웨덴 기업의 국제경쟁력을 하락시킨다고 주장하였다.

1976년에 집권한 우파정부는 복지급여를 축소하고 의료 및 주택에 대한 수혜자 부담원칙을 도입하 였고 사회서비스의 비용 절감을 추진하였다. 1982년에 재집권한 사회민주당 정부도 복지개혁을 시도 하였는데 연금개혁을 위한 연금위원회가 1984년에 설치되었다. 1980년대까지 OECD 국가들 가운데 거의 유일하게 완전고용을 유지했던 스웨덴은 1990년대 들어 전후 최악의 실업률을 기록하게 되었 다. 이러한 노동시장의 문제는 곧 바로 복지국가의 위기로 발전하였다. 완전고용 자체가 스웨덴 복지 국가의 핵심적 내용이었을 뿐 아니라, 실업증가와 고용감소는 재정에 이중의 부담을 안겨주었기 때 문이다. 1976년 GDP의 3.6\%에 불과했던 재정적자는 1982년에는 $16.3 \%$ 로 늘어났으며, 외채 또한 급 격히 늘어났다. 재정적자를 해소하기 위한 제 1 순위로 복지지출의 삭감이 추진되면서 스웨덴 복지국 가의 재편이 불가피해졌다. 이러한 상황에서 세계화와 유럽통합의 가속화는 복지국가의 재편을 재촉 하였다.

본격적인 개혁은 1991-2년 금융위기를 극복하는 과정에서 우파연립정부와 사회민주당이 1992년 시장의 역할을 강화하는 것을 골자로 한 정책프로그램(Crisis Package)에 합의함으로서 구체화되었 다. 이 정책프로그램은 복지수당의 축소, 복지행정기구의 재편 등 사회복지에 대한 국가개입을 축소 하는 내용을 포함하고 있었다. 공공부문의 재정적자를 축소하기 위한 방안의 하나로 추진된 공공부 문의 고용축소는 민간부문의 고용감소와 맞물려 급격한 실업증가를 가져왔다. 1990 년대 초반은 사회 복지제도 뿐 아니라 조세제도의 개혁이 동시에 이루어지면서 스웨덴 복지국가가 근본적으로 변화한 시기였다. 1991 년 세제개혁의 큰 특징은 한계세율을 낮추는 것과 더불어 개인소득세에 대한 종합과 세를 분리과세로 이행시킨 것이었다. 이와 함께 개인소득세와 법인소득세의 세율이 대폭 하향조정되 고 간접세인 부가가치세가 인상되었을 뿐 아니라 다양한 세금감면제도가 철폐되었다.

1990 년대 중반의 재정건전화 계획은 지출축소와 세입증가에 초점이 맞추어져 있었다. 개인의 책 임을 강조하고 경제활동에 대한 동기부여를 강화하면서 전반적으로 복지제도가 혜택중심에서 급여중 심으로 전환되면서 스웨덴 복지체제의 특징인 보편성이 약화되는 경향을 보였다. 보험급여율이 삭감 되고 대기기간이 도입됨에 따라 보장의 완벽성도 약화되었다. 반면, 사회서비스제도에서는 변화가 거의 없다. 스웨덴 복지국가는 1998 년 6 월 5 개의 여 - 야정당 공동의 복지개혁법이 의회에서 통과됨 에 따라 또 다시 재편되었다. 1984년 연금제도 개혁을 위한 연금위윈회가 설치된 후 14 년 만에 새로 운 연금제도 개혁법안이 의회에서 승인된 것이다. 노동인구 대비 노령연금 수령자의 수가 증대되고 평균수명이 길어짐에 따라 연금 수혜기간도 길어지고 총연금액수도 커질 수 밖에 없기 때문에 노령 연금을 축소하고 연금제도를 보다 노동친화적으로 만들었다.

1990년대 들어 많은 복지개혁이 이루어졌지만 스웨덴 복지국가는 여전히 견고성을 유지하고 있다. 복지개혁에도 불구하고 사회서비스, 의료 등의 영역에서는 민영화로 대표되는 시장중심적 개혁이 등 장하지 않고 있다. 물론, 현재의 스웨덴 복지국가는 과거의 것과 다르다. 사회적 평등을 위한 종전의 
정책적 수단이 제약받고 있기 때문이다. 세계화, 산업구조의 변화, 인구 및 가족구조의 변화, 가치관 의 변화 등 다양한 국내외적 요인이 복지국가의 재편을 요구하고 있다. 개인주의적 가치관이 심화되 면서 선택적 복지의 요구가 크게 나타났다. 국가에 의한 사회보장과 사회서비스의 상당부분이 지방 자치단체로 이전되는 현상이 나타나고 있다. 무엇보다 인구 및 가족구조의 변화는 복지국가를 어려 움에 처하게 만들고 있다. 노령화, 편부모 및 맞벌이 가정의 증가에 따른 가족구조의 변화는 소득이 전의 복지체제에 새로운 변수로 작용하고 있다. 다행히, 스웨덴 복지국가는 여성이 일과 가정을 병행 할 수 있는 성 평등정책을 시행함으로써 우리가 경험하고 있는 저출산의 위험에 직면해 있지는 않다. 1994년 집권 이후 스웨덴 사회민주당 정부는 비용억제와 프로그램 합리화로 점진적인 복지개혁을 추 진해 왔다. 복지개혁이 복지기생자를 줄이는데 초점이 맞추어져 있기 때문에 복지국가라는 시스템 자체의 변화는 나타나지 않고 있다.

스웨덴 복지국가의 정치적 기반은 경제적 성과와의 적합성, 그리고 중산층 이상의 유권자에게 양 질의 사회서비스를 제공할 수 있는 능력에 달려있다. 이는 곧 소비부문의 계급양극화를 가져오지 않 는 범위에서 공공서비스의 선택권을 확대하고 동시에 양질의 서비스를 위해 세금을 더 많이 걷는 일 이 발생하지 않는 것을 의미한다. 복지국가의 효율성이 크게 높아진 것이다. 1990 년대 이후 경제 효 율성에 미치는 분배정책의 부정적 영향은 크게 완화되었다. 사회서비스의 비효율, 세금 및 복지급여 로 인한 개인적 선택의 왜곡, 도덕적 해이 등의 문제가 크게 개선되어 왔기 때문이다. 특히, 공공부 문의 효율성이 높아지고 세제개혁으로 세금왜곡을 줄였으며 임금대체율을 낮춤으로서 복지급여문제 도 완화되었다. 스웨덴 복지국가는 사회보장과 사회서비스의 측면에서 여전히 뛰어난 제도를 유지하 고 있다. 오히려 복지국가의 후퇴가 정치적으로 위험하다는 결과가 실제로 나타나고 있는 실정이다. 2006년 총선과 2010년 총선에서 우파연합이 친복지 공약을 내세운 것도 이러한 이유에서이다.

세계화 시대에도 스웨덴 복지국가는 견고하다. 스웨덴 국민들은 성장이 지속되고 질 높은 복지서 비스를 제공하는 복지국가에 여전히 매우 우호적이기 때문이다. 서유럽에 비해서도 상대적으로 높은 국민적 지지에 기초하여 스웨덴 정치인들은 복지국가가 사회 · 경제적으로나 정치적으로 지속될 수 있도록 노력하고 있다. 1980년대 이후 정치경제의 많은 구조적 변화에도 불구하고 급격한 복지개혁 은 이루어지지 않았다. 스웨덴 복지국가의 특성상, 노동계층은 물론 중산층을 포함한 광범위한 복지 수혜 계층이 존재하기 때문에 우파정부도 역사적으로 형성된 복지국가에 대한 사회적 합의를 존중하 고 있다.

스웨덴 사회는 1990 년대에 많은 변화가 있었다. 노령화의 심화와 외국인의 증가라는 인구변화 뿐 아니라, 산업구조가 변화함에 따라 노동생활 및 노동시장에서도 큰 변화가 나타났다. 경제의 탈규제 와 자본, 노동 등 생산요소의 국제적 이동은 경제조건과 경제규칙을 변화시켜 왔다. 이러한 국내외의 변화가 복지정책에 큰 도전이 되었다. 스웨덴 복지국가는 부단한 개혁과 변화의 결과, 경쟁력을 유지 하면서 복지의 질을 유지하고 있다. 스웨덴에서 복지국가의 정당성은 거의 훼손되지 않았으며 복지 국가에 대한 유권자들의 지지는 여전히 강고하며 광범위하게 나타나고 있다. 더욱 중요한 점은 스웨 
덴 복지국가가 국민들의 사회정의에 대한 강한 믿음과 높은 세금윤리에 기반해 왔다는 것이다. 다수 의 국민과 정당은 복지국가를 경제사회적 여건 뿐 아니라 가치와 이념의 기준에서 변화의 정도와 방 향을 결정한다는 점이다. 경제적 상황이 어렵다고 해서 평등과 연대의 가치를 실현해 준 복지국가 자 체를 포기하지는 않는다는 것이다.

노동참가와 육아를 동시에 가능하게 하는 공공 사회서비스, 적극적 노동시장정책을 통한 노동력의 동원, 인적자본 개발에 대한 강조 등 전통적인 스웨덴의 분배정책은 오히려 세계화라는 새로운 경제 환경에 대한 적응을 용이하게 하고 있다. 세계화 시대에도 복지국가 스웨덴이 경쟁력을 가질 수 있는 이유는 성장과 개혁, 분배를 위해 부단히 노력해 왔기 때문이다. 1970 년대 이후 스웨덴 모델이 위기 를 경험했지만 1980 년대와 90 년대 시장자유화 및 제도개혁은 경제를 근본적으로 재구조화시켰다. 세제개혁, 연금개혁 등으로 복지국가의 효율을 높여왔다. 노인인구가 증가하고 저출산으로 공공사회 서비스에 대한 요구는 증가하는 현실에 대응하여 노인, 여성, 아동에 대한 복지가 지속적으로 늘어나 는 것도 이 때문이다.

사회구성원의 소득과 복지수준은 그 나라의 경제적 조건과 상황으로부터 크게 영향을 받게 된다. 경제성장, 효율성, 거시경제적 안정을 얼마나 달성하느냐에 복지국가의 앞날이 달려있기 때문이다. 스웨덴 국민들은 경제적 성공이 고복지와 사회통합 등 스웨덴이 추구하는 사회적 목표를 실현시켜 준다는 인식을 가지고 있다. 경제상황이 나빠질수록 복지수요는 늘어나게 되고 그만큼 더 많은 자원 이 복지를 위해 지출될 것이다. 이러한 상태가 오래갈수록 생산은 물론 복지를 위한 자원도 고갈되어 많은 사람의 경제적 안전이 위험에 처하게 된다. 따라서 장기적 경제성장과 고용증대를 창출할 수 있 는 국가능력은 매우 중요하며, 이를 위해 복지국가는 높은 수준의 인적자본 투자와 노동참여를 높이 기 위해 노력하게 된다.

\section{IV. 스웨덴 복지모델과 국제개발협력: 경제적 기회와 사회적 안전망 확대를 위한 국제개발협력}

\section{1. 빈곤추방과 경제적 기회를 보장하는 스웨덴 복지모델과 국제개발협력 전략}

스웨덴 국제개발협력의 기본 목표는 빈곤추방에 있다. 이는 20 세기 초 스웨덴 복지국가의 태동기 에 목표로 했던 빈곤추방과 같은 맥락에서 이해될 수 있을 것이다. 빈곤을 없애기 위해서는 각 개인 에게 능력제고의 기회를 주는 것이 중요하게 된다. 교육 등 인적자본에 대한 투자가 그것이다. 스웨 덴은 일찍부터 공교육을 강화하여 20세기 초 유럽에서 문맹률이 가장 낮은 국가였다. 스웨덴의 교육 제도는 20 세기 들어, 특히 2 차 세계대전 이후 정치적, 경제적 발전과 궤를 같이 하여 개혁을 해왔다. 
교육개혁을 사회개혁의 맥락에서 파악하고 모든 교육상의 과제들을 사회정책과 연관하여 해결해 왔 다. 사회정의의 이념과 교육기회의 평등이라는 민주적 원리에 기반하여 교육이 이루어져 왔던 것이 다(변광수 2005). 아동에 대한 보육 및 교육은 19 세기 말부터 시작되었으며 대부분 공공기관에 의해 운영되어 왔다. 이들 기관은 부모의 수입정도에 따라 실비의 요금으로 취업부모의 아이들을 맡아 돌 봐주면서 아동들의 사회적, 정서적, 지적 발달을 지원하고 있다. 이러한 아동보육은 부모의 취업활동 을 용이하게 할 뿐 아니라 여성들을 가사노동으로부터 해방시켜 사회활동을 하게 만드는 것이다. 성 평등을 실현시키는 것이다.

유년기 교육 후 9 년제 무상의무교육인 기초학교는 학생들이 직업생활과 사회생활을 잘 할 수 있도 록 전인적인 교육을 실시한다. 2-3년의 고등학교 교육도 무상교육으로 직업교육이 활성화되어 있으 며 고등학교와 대학교육을 받는 학생들은 학업보조금을 받을 수 있다. 스웨덴에서 중요한 교육이 평 생교육제도이다. 이 제도는 교육의 기회를 놓친 청소년 뿐만 아니라 대학출신의 기성 직장인에게도 적용되어 새로운 지식에 대한 욕구나 기존 지식을 보강하기 위해 이용한다. 평생교육제도 또한 무상 이다. 1977 년에는 교육기회를 확대하여 사회계층 및 성별에 따른 고등교육 기회의 불균형을 시정하 기 위해 대학교육을 개혁하였다. 최근에는 교육의 다양성과 교육 주체간 경쟁을 유도하기 위해 공교 육 개혁을 추진하기도 하였다.

교육제도에서 알 수 있듯이, 스웨덴 복지모델은 개인의 사회경제적 기회와 안전망을 확대하는 데 그 목적이 있다. 이를 위해 교육과 고용의 기회를 보장하고 있다. 고용을 복지의 첫걸음으로 인식하 여 가능한 한 많은 사람이 인간적인 근로환경에서 자신의 적성과 능력에 맞게 일을 잘하도록 만드는 것이다. 스웨덴 모델의 분배정책은 처음부터 효율을 중시하였으며 단순히 현금지원에만 그치는 것이 아니라 교육과 고용을 강조함으로서 생산적 복지정책을 시행해왔다. 완전고용과 교육훈련제도는 고 세금에 의한 평등한 분배정책이 효과적으로 실현될 수 있는 기반이 되었다. 평등주의 정책으로 일컬 어지는 동일업종 내의 임금평준화 정책, 즉 동일노동 동일임금 정책은 계층간 격차를 줄이는데 크게 기여하였다. 노동보호 제도 및 인적자본 정책은 개인의 사회경제적 기회를 보장하는데 중요한 요소 이다. 비정규직인 기간제 근로자 및 육아휴직 근로자에 대한 보호규정도 강화되고 있다.

시장친화적 정책은 효율성을 높여 성장을 달성하는데 기여하였고 이를 기반으로 고용 증대, 인적 자본에의 투자 확대, 생산적인 복지, 삶의 질 향상 등을 성취해 왔다. 재정지출은 1960 년대부터 크게 늘어나게 되었는데, 보육서비스, 교육 및 직업훈련, 보건 - 의료 등과 같은 투자적 성격의 사회인프 라에 집중하였다. 고용을 늘리고 사회 전반적으로 안전도를 높여 그만큼 실업급여, 산재급여, 공공부 조와 같은 소비적 지출을 최소화하였다. 성장과 고용, 고숙련의 인적자본과 생산적인 복지가 스웨덴 을 만들었던 것이다.

스웨덴 복지모델의 중요한 특징은 개인들에게 사회적 기회와 경제적 기회를 보장하기 위해 공공사 회서비스가 뛰어나다는 점이다. 이와 함께 적극적 노동시장정책은 개인의 역량을 제고하여 고용가능 성을 높이는데 기여해왔다. 또한 인적자본에 대한 대대적인 투자는 사회자본의 기본이 되는 개개인 
의 능력을 계발하고 사회에 참여할 수 있게 해준다. 이러한 성격들은 사회전반의 효율성을 높이고 경 제성장을 가져오는데 중요한 역할을 하고 있다. 성평등도 이러한 맥락에서 이루어졌다.

스웨덴 복지국가모델은 1930년대 스웨덴 경제학자로 노벨경제학상을 받은 군나르 뮈르달(Gunnar Myrdal)이 제시한 사회민주주의형 모델이다. 뮈르달의 '생산적 복지' 모델은 저소득층에 직접 급여를 나누어주는 복지체제 대신, 모든 국민에게 생활에 필요한 서비스를 국가가 직접 제공하는 사회서비 스 중심의 복지국가 전략이었다. 의료, 교육, 보육, 노인요양과 같은 서비스를 정부가 직접 운영, 제 공함으로써 일정 수준 이상의 삶을 모두에게 보장하는 것이다. 실제로 스웨덴은 영미모델은 물론, 독 일, 네덜란드 등 대륙모델과 달리 사회서비스 인프라 수준이 매우 높고, 실업수당 중심의 소극적 노 동시장정책보다 교육, 훈련 중심의 적극적 노동시장정책 지출이 훨씬 많다. ${ }^{8)}$

스웨덴 복지국가는 1960 년대에 접어들면서 소득대체가 가능할 정도의 사회적 급부시스템이 구축 되기 시작하였다. 1970 년대까지 사회보험, 공적부조, 사회서비스 등 모든 사회복지제도가 완비되었 다. 그 결과, 스웨덴에서는 노동계급과 중간계급이 모두 보편적 사회보험 프로그램을 통해 제공되는 국가복지의 틀에 의해 통합되어 있으며, 복지는 시민적 권리이자 사회적 권리로 인식되게 되었다. 연 금을 제외한 사회보험의 소득대체율은 거의 $90 \%$ 수준에 달하였다. 사회보험의 높은 소득대체율은 평등주의를 강조한 분배정책 때문이며, 기여와 급여 간의 관계가 약한 스웨덴 복지제도의 특징을 보 여주고 있다. 공적부조와 함께 기여와 급여가 분리된 기본연금제도는 중요한 재분배 기능을 수행해 왔다. 그 결과, 소득평등 수준이 매우 높아 가장 모범적인 복지국가로 평가받아 왔다. 사회보험제도 보다 더 뛰어나다고 평가받는 스웨덴 복지국가의 특징은 탁아, 노인 보살핌 등 완벽한 사회서비스를 정부가 제공하는데 있다. 이러한 사회서비스의 재정지출은 $\mathrm{EU}$ 평균의 두 배에 이른다. 스웨덴은 공 공부조나 사회보험을 기본으로 하면서도 탁아, 교육, 의료, 교통 등 직접적인 사회서비스가 거의 무 료로 전국민에게 제공된다.

\section{2. 사회통합을 위한 스웨덴 복지모델과 국제개발협력 전략}

스웨덴의 정부정책은 무엇보다 성장, 고용, 공공복지, 사회통합을 목표로 하고 있다. 특히, 사회통 합을 위해 일자리 보장, 임금격차의 축소, 빈곤감소, 삶의 조건의 동질화 등을 추구하고 있다. 사회 통합이 규범적 차원에서 주창되는 것이 아니라 제도와 정책, 실질적인 사회경제적 성과에 의해 달성 되는 것이다. 스웨덴의 국제개발협력 전략이 경제사회적 기회 제공과 사회안전망에 기반하고 있는

8) 복지국가는 지역별로 나라마다 다양한 형태와 특징을 가지고 있다. 미국의 복지정책은 극빈자를 주 대상으로 한 공공부 조 중심으로 되어있다. 따라서 미국에서는 복지제도의 수혜자가 매우 소수일 수밖에 없다. 조합주의형 또는 유럽대륙형 으로도 불리는 독일의 복지제도는 고용근로자를 주 대상으로 사회보험제도가 근간을 이룬다. 물론 공공부조는 기본적으 로 제공된다. 스웨덴은 영미형은 물론, 독일과도 상당한 차이가 있다. 1990년대 이후 각국의 복지개혁으로 유럽대륙형 과 북유럽복지모델의 차이가 약화되고 있다. 독일 등 대륙 국가들이 가족정책 등 공공사회서비스를 확대하고 적극적 노 동시장정책을 도입하였기 때문이다. 
것도 스웨덴의 사회통합에 기반한 국가발전 전략과 관련된다. 스웨덴은 계층, 성별 등 다양한 사회적 차원에서 사회통합을 목표로 하였고 이를 성취해 왔다.

스웨덴 복지국가는 이인부양자모델(Dual-Breadwinner Model)에 기반하고 있어 여성의 노동시 장 참여율을 높이는 역할을 하는 것도 중요한 특징이다. 무상 혹은 국가보조를 받는 공공탁아서비스 는 관대한 아동 및 가족수당, 부모보험과 함께 복지국가를 여성친화적으로 만들고 있다. 노동시장 참 여와 육아를 양립시키며, 동시에 사회적으로 요구되는 출산율을 유지시키는 데에도 영향을 주고 있 다. 스웨덴의 탁아서비스는 높은 수준의 질과 보편적 이용이라는 원칙에 의해 시행되고 있다. 취학어 린이도 방과후센터에 다닐 수 있으며 학교휴일에도 열고 있다. 여성노동력의 증가는 대부분의 가구 에 적용되는 높은 세율로 혼자 벌어서는 가계를 꾸리기 어려운 점에도 기인한다. 이 점에서 한국 중 산층 여성은 행복하다고 할까. 일할 수 있는 사람은 모두 일하게 만드는 완전고용정책과 권리뿐 아니 라 의무에서도 '성평등'을 지향하는 정부정책은 노동시장에서 특별히 여성을 배려하기보다 젠더중립 적 입장에서 여성이기 이전에 근로자로 인식해왔다. 20 세기 초부터 부족한 노동력을 여성들이 채우 면서 고용평등정책이, 1960 년대 이후 공공서비스부문의 엄청나게 증가한 노동력 수요로 여성의 노동 시장참여율이 높아지면서 많은 분야에서 성평등이 보다 확고해졌다.

스웨덴 복지국가의 가장 큰 문제는 사회복지제도를 유지하는데 비용, 즉 세금이 많이 든다는 점이 다. 이 때문에 낮은 실업률을 유지하여 수혜대상자를 가능한 한 감소시키는 전략을 추진해왔다. 적극 적 노동시장정책이라는 제도적 장치를 통해 복지비용을 최소화하면서 세입을 극대화하는데 성공함으 로서 포괄적 사회복지제도가 갖는 비용의 문제를 어느 정도 해결할 수 있었다. 높은 노동비용만큼 노 동생산성의 증가를 가져오게 함으로써 기업의 경쟁력과 완전고용을 유지하는 데 성공한 것이다. 물 론, 스웨덴의 모든 국민이 높은 세금에 기반한 국가복지를 지지하는 것은 아니지만 1932년 사회민주 당 집권 이후 다수의 유권자가 이에 동의해 왔기 때문에 세계 최고의 복지국가를 만들 수 있었던 것 이다. 사회민주당의 장기 집권으로 분배정책은 다른 정당에도 중요한 영향을 미쳐 복지정책에 대한 이념적 차이를 축소시켰다. 또한 노조의 영향력 확대뿐 아니라, 노령인구가 증가하고 여성노동력 참 여가 크게 확대되면서 이들은 관대한 연금, 탁아 및 노인보살핌 등 사회서비스에 대한 정치적 압력을 크게 가했다. 이들은 복지국가를 지지하는 강력한 기반이 되어 왔다.

기존의 적극적 노동시장정책 외에도 인적자본의 질을 높이기 위해 정규교육을 강화하는 새로운 정 책을 추진하고 있다. 스웨덴 정부는 재교육, 직업훈련 등 평생교육의 기회를 확대함으로써 인적자본 의 기초를 개선하려는 노력을 지속해 왔다. 이러한 노력은 공공부문 팽창에 의한 고용창출이 더 이상 가능하지 않은 상태에서 고실업이냐, 아니면 민간서비스부문의 저임근로자 양산이냐라는 양자택일 상황을 피할 수 있게 해주고 있다. 노조는 저학력 성인근로자의 노동시장 경쟁력을 위해 더 많은 직 업훈련과 교육을 제공하는 정책을 사회민주당에 요구해 왔다. 적극적 노동시장정책은 인적자본의 질 을 높이는데 초점이 맞추어져 있으며 노사협력에 기반하여 '고숙련-고부가가치-고임금 전략'을 시행 하고 있다. 고숙련 노동력이 스웨덴 경제를 발전시키는 데 크게 기여하고 있는 것이다. 
불평등을 감소시키고 인적자본의 질적 향상을 위한 노력은 고숙련/고임금 수출산업의 대외경쟁력 을 유지시키는데 있어서 뿐 아니라, 내수산업의 생산성 제고를 위해서도 힘이 되고 있다. 높은 생산 성과 높은 수준의 고용은 다시 높은 수준의 복지국가를 유지하는데 필수불가결한 세금원을 제공하고 있는 것이다. 스웨덴은 고부가가치 제조업 및 고부가가치 서비스산업의 경쟁력 향상을 목표로 하고 있다. 그럼에도 탈규제된 저임서비스직과 안정된 고임금 고용이라는 부문별로 분리된 '이중노동시장' 이나 '이중경제(Dual Economy)'를 수용하지 않고 있다. 바로 사회통합의 기반은 경제적 기회와 사회 적 안전을 보장하는데 있다고 보기 때문이다. 저학력, 저숙련 근로자에 대한 교육과 기술훈련을 강화 하는 방식을 채택하여 '두 계급의 노동시장(Two-Class Labor Market)'을 지양하고 있는 것이다. 노 동시장의 균형발전을 추구하는 'Win-Win'전략이 가능한 것은 스웨덴의 노동시장과 단체협상, 노조 등 강력한 노동시장제도들이 상호 긴밀히 연관되어 있기 때문이다. 기술수준에 따른 실업의 격차가 커지면서 정부는 기존의 노동시장정책 외에도 정규교육을 강화하는 새로운 정책을 추진하였다. 정규 교육에 의한 인적자본 투자는 노동시장에서 근로자가 직면할 위험을 줄이는 가장 좋은 방법으로 보 기 때문이다.

역사적으로 스웨덴의 국가발전 과정에 정당과 국가, 기업 뿐 아니라 스웨덴 시민사회가 중요한 역할을 해 왔다. 스웨덴 사회의 높은 사회적 신뢰와 규범, 투명성은 시민사회가 신뢰와 규범을 생산 해내고 유지시키는 공식 비공식의 제도와 문화를 만들어 왔기 때문이다. 1980년대 이후 스웨덴 모델 에 적지 않은 변화가 있었지만 스웨덴 사회의 정체성은 크게 훼손되지 않았다. 사회적 합의 전통은 여전히 강하게 작동하고 있으며 복지국가는 구조조정을 통해 효율성과 효과성을 높이고 있다. 높은 수준의 복지가 경제적으로 부정적인 결과를 초래할 수 있다고 하지만 스웨덴은 $\mathrm{EU}$ 평균보다 높은 경 제성장률과 낮은 실업률을 보인다.

자본주의의 재구조화와 세계화에 불구하고 스웨덴의 전통적 가치와 제도는 지속되고 있다. 평등과 연대, 사회통합에 대한 국민들의 지지가 강고하기 때문이다. 이러한 배경에 스웨덴 복지국가가 있다. 스웨덴 복지국가는 투자적 성격의 재정비중이 높은 특징을 가지고 있다. 즉, 사회투자를 늘림으로써 사회구성원들이 교육, 건강, 일, 안전, 사회적 신뢰, 정치적 자원 등을 더 많이 갖고 누리게 만드는 것이다. 이는 좋은 복지국가로 가는 지름길이 된다.

\section{V. 결 론}

성장과 복지를 함께 추구하는 국가발전전략을 선택한 스웨덴이 국제개발원조에 있어서도 스웨덴 복지모델의 성격이 반영되고 있다. 개도국 국민들의 경제적 기회와 사회안전망을 제고하는 국제개발 협력의 정책 및 전략 측면에서 국제사회의 모범이 되고 있다. 주요 선진공여국으로서 원조 규모에서 $\mathrm{GNI}$ 대비 $1 \%$ 가 넘을 뿐 아니라 빈곤퇴치와 일자리, 역량강화를 위해 적극적이고도 효과적으로 개발 
협력 활동을 하기 때문이다. 스웨덴은 성장과 복지가 양립하는 복지모델 전략으로 사회적 평등과 경 제적 안전을 보장해 왔다. 1930년대부터 적극적이고 생산적인 복지제도의 도입과 발전, 1990년대 이 후 복지개혁으로 복지국가의 경쟁력을 제고함으로서 사회경제적 성과를 달성하는데 중요한 역할을 하고 있다.

스웨덴의 국제개발원조는 국내적 요소와 밀접한 관련을 갖는다고 할 수 있다. 즉, 개발원조의 전 략과 내용, 추진 방식과 과정, 효과성과 효율성의 강조 등은 역사적으로 스웨덴 복지모델이 발전해온 과정 및 성격과 유사하다. 물론, 대부분의 원조공여 국가들이 이러한 요소를 중시하고 있을 것이다. 그러나 실질적으로 이러한 목적을 달성하고 효과성을 높이기 위해 적극적이고 생산적으로 개발협력 프로그램을 운영하는 것이 중요하며 이는 공여국의 역량 그 자체에 달려있다고 할 것이다. 스웨덴 사 례는 이를 잘 보여준다. 스웨덴의 구체적인 개발협력 전략과 프로그램이 스웨덴의 복지국가 전략 및 정책의 성격을 반영하고 있기 때문이다. 적극적이고 생산적인 개발원조, 공평하고 지속가능한 개발 원조, 투명하고 신뢰할 수 있는 개발원조가 그것이다.

국제개발협력에서는 자신들이 잘 할 수 있는 분야에서, 자신의 경험을 살릴 수 있는 해외원조 프 로그램이 중요하다. 사회경제적 기회의 확대, 복지 및 사회안전망 확대는 스웨덴의 국제개발협력 프 로그램의 기본 원칙이 되고 있다. 이를 바탕으로 민주주의 의식 고양, 지역경제의 자립 지원, 인권 보호를 위한 인프라 구축 지원, 평화와 안전, 교육, 빈곤퇴치, 의료보건, 양성평등 등이 주요 개발협 력의 목표이다. 인권과 민주주의는 이러한 물적 조건과 함께 한다고 보는 것이다. 스웨덴은 성평등 수준이 가장 높은 나라이다. 국제개발협력에서 양성평등을 중시하고 여성의 역량강화를 강조하는 것 도 이러한 맥락이다. 다양한 사회적 인프라 구축은 스웨덴이 20 세기 초중반에 대대적으로 실행한 것 으로, 지금까지 경쟁력 있는 스웨덴 복지국가를 위한 기반이 되어 왔다. 스웨덴의 국제개발협력 전략 사례는 한국의 개발원조정책의 발전 방향에 대해 시사하는 바가 크다 할 것이다. 


\section{참고문헌}

\section{1. 국내문헌}

김미경. 2010. “왜 노르딕 국가들은 더 많이 원조를 하는가?” 2010 한국유럽학회 연례학술대회 발표 논문(2010.12.11)

김인춘. 2007. 『스웨덴 모델, 독점자본과 복지국가의 공존』 삼성경제연구소

김채형. 2000. “유럽연합의 개발협력정책” ${ }^{\circledR} \mathrm{EU}$ 학연구』제 5 권 제 2 호

변광수. 2005. 『스웨덴, 스웨덴사람들』서울: 문예림

안재흥. 2004. “근대로의 이행과 스웨덴 정치”, 『유럽정치』백산서당

이주경. “성장과 분배, 윈-윈의 길을 찾아서” http://blog. naver.com/wilddog25/60005773330

주은선. 2006. “스웨덴 복지정치의 기반변화: 코포라티즘의 폐기 혹은 변형?" 『사회보장연구』 22 권 1 호

주한 스웨덴 대사관 “스웨덴 복지모델의 성공요인 - 정치구조 및 환경측면” 2006. 2

\section{2. 국외문헌}

Bergh, Andreas \& Gissur Erlingsson. 2006. "Resilience through Restructuring: Swedish Policy-making style and the Consensus on Liberalizations 1980-2000" Stockholm: The RATIO Institute, Bergman, Annika. "The Domestic Construction of Nordic Foreign Policy: The case of Global Welfare and Solidarity", paper presented at the 2005 ISA Annual Convention, Honolulu, Hawaii, March 1-5, 2005

Boix, Carles. 1998. Political Parties, Gronth and Equality: Conservative and Social Democratic Economic Strategies in the World Economy Cambridge: Cambridge University Press

Esping-Andersen, Gosta. 1990. The Three Worlds of Welfare Capitalism Princeton: Princeton University Press

Gylfason, Thorvaldur (ed.). 1997 The Swedish Model under Stress: A View from the Stands. Stockholm: SNS.

Hadenius, Axel. 2008. Democracy and Development Cambridge University Press Hadenius, Stig. 1988. Swedish Politics during the 20th Century The Swedish Institute Heclo, H. and Henrik Madsen. 1987. Policy and Politics in Sweden: Principled Pragmatism, Philadelphia: 
Temple Univ. Press.

Lane, Jan-Erik (ed.). 1991. Understanding the Swedish Model Routledge

Lawler, Peter. 1997. "Scandinavian Exceptionalism and European Union" Journal of Common Market Studies vol.35 no. 4: 565-94

Lindbeck, A. 1997. The Swedish Experiment, Stockholm: SNS

Lumsdaine, D.H. 1993. Moral Vision in International Politics: The Foreign Aid Regime, 1949-1989, Princeton: Princeton University Press

Mosley, P. 1985. ":The Political Economy of Foreign Aid: A Model of the Market for a Public Good" Economic Development and Cultural Change vol 33 no.2: 373-393

Pierson, Paul (ed.). 2001. The New Politics of the Welfare State Oxford: Oxford University Press

Noel, Alain and Jean-Philippe Therien. 1995. "From Domestic to International Justice: The Welfare state and Foreign Aid", International Organization vol.49 no. 3: 523-553

Stein, Peter. 1991. "Sweden: From Capitalist Success to Welfare-State Sclerosis" Policy Analysis no. 160 Washington D.C: The Cato Institute

Therien, Jean-Philippe. 2002. "Debating Foreign Aid: Right versus Left" Third World Quarterly vol.23, no.3: $449-466$

Trägårdh, Lars(ed.). 2007. State and Civil Society in Northern Europe: The Swedish Model Reconsidered Berghahn Books

Whyman, Philip. 2003. Sweden and the 'Third Way': A Macroeconomic Evaluation Aldershot: Ashgate Zanger, Sabine C. 2000. Good Governance and European Aid: The Impact of Political Conditionality European Union Politics 1: 293-317

OECD, "Sweden: Achieving Results for Sustained Growth" March 2007, OECD Policy Brief http://www.eiro.eurofound.ie

Sweden(2000), Development Co-operation Review

(http://www.oecd.org/document/15/0,3746,en_2649_34603_1883855_1_1_1_1,00.html)

DAC Member's Commitments and Performance: Summary Tables of OECD Secretariat Projections (http://www.oecd.org/dataoecd/17/12/44981982.pdf)

Development aid rose in 2009 and most donors will meet 2010 aid targets (http://www.oecd.org/document/0,3746,en_2649_34447_44981579_1_1_1_1,00.html)

Sweden (2009) DAC Peer Review - Main Findings and Recommendations (http://www.oecd.org/document/1/0,3746,en_2649_34603_43278401_1_1_1_1,00.html) 